\title{
A simplified method for determining erythrocyte pyrimidine 5 '-nucleotidase (P5N) activity by HPLC and its value in monitoring lead exposure
}

\author{
T SAKAI, K USHIO
}

From the Center of Occupational Medicine, Tokyo Labor Accident Hospital, Ota-Ku, Tokyo 143, Japan

\begin{abstract}
The method for determining erythrocyte pyrimidine 5 '-nucleotidase (P5N EC 3.1.3.5) activity has been simplified using an automated high performance liquid chromatograph (HPLC). The activity determined by the simplified method agreed closely with that obtained by conventional methods. In 161 lead workers P5N activity declined linearly with increasing blood lead concentrations $(\mathrm{Pb}-\mathrm{B})$ between 20 and $80 \mu \mathrm{g} / 100 \mathrm{~g}$, and correlated well with $\mathrm{Pb}-\mathrm{B}(\mathrm{r}=-0.87)$. For the same group of workers, correlation coefficients between $\mathrm{Pb}-\mathrm{B} v \mathrm{ALA}-\mathrm{D}$ activity, zinc protoporphyrin, ALA-U, and coproporphyrin were $-0 \cdot 87,0 \cdot 73,0 \cdot 70$, and $0 \cdot 32$, respectively. At $\mathrm{Pb}-\mathrm{B}$ $\geqslant 40 \mu \mathrm{g} / 100 \mathrm{~g}$, the validity of P5N (1.86 at a cut off of $10 \leqslant$ units) was higher than that of other indicators examined. P5N activity was fairly stable during the storage of samples for two weeks at $4^{\circ} \mathrm{C}$. Determination of P5N activity by this method may be a useful indicator in screening for moderate exposure to lead.
\end{abstract}

Pyrimidine 5'-nucleotidase (P5N, EC 3.1.3.5) was first reported by Valentine et al in 1974 in their description of haemolytic anaemia. ${ }^{1}$ The enzyme in the red cell cytosol catalyses the hydrolytic dephosphorylation of pyrimidine $5^{\prime}$-monophosphates but is ineffective on purine nucleotides. The reaction is thought to be a necessary step in the degradation of ribosomal RNA in maturing red cells. Through this mechanism, the erythrocyte is able to diffuse pyrimidine nucleotides as soluble nucleosides and retain purine nucleotides as a source of ATP.

The activity is extremely reduced in certain hereditary non-spherocytic anaemias and in lead poisoning. ${ }^{1-3}$ Many investigators have confirmed that the measurement of P5N activity has a diagnostic value for these disorders. ${ }^{4-6}$ Several workers have also reported negative linear correlations between blood lead concentrations and P5N activity in lead workers. ${ }^{3-9}$ Thus the measurement of P5N activity appears to be a useful index of lead exposure or lead poisoning. Despite this, there have been few reports in which P5N activity has been determined as an index of lead exposure.

The conventional method for measuring P5N activ-

Accepted 24 March 1986 ity is based on the liberation of inorganic phosphorus from pyrimidine 5 -nucleotides and requires timeconsuming and complicated procedures, limiting its application in a clinical laboratory. ${ }^{1}$

We have previously developed a rapid and sensitive method of determining P5N activity, using reversed phase high performance liquid chromatography (HPLC) ${ }^{10}$ In the present paper we report on a further simplification of the method and its use in evaluating lead exposure. We have also studied the relation between $\mathrm{P} 5 \mathrm{~N}$ activity and other biological parameters of lead exposure.

\section{Materials and methods}

Heparinised venous blood was obtained from 161 lead workers who were employed in secondary smelters, glass factories, storage battery plants, and printing offices. To determine P5N activity, the erythrocytes were washed twice with a tenfold volume of saline $(0.9 \% \mathrm{NaCl})$ and then suspended in the saline (about $50 \%$ suspension; RBC/saline). P5N activity was determined by the method previously reported ${ }^{10}$ with some modifications. We modified the preparation of the reaction mixture as follows: the enzyme solution was prepared by diluting $50 \mu \mathrm{l}$ of $\mathrm{RBC} /$ saline to $600 \mu \mathrm{l}$ with distilled water. Commercially available UMP- 
$\mathrm{Na}$ (uridine $5^{\prime}$-monophosphate disodium salt) was used as the substrate without any purification instead of buffered substrate in the original method. ${ }^{8}$ The standard assay mixture contained $600 \mu$ l of enzyme solution, $100 \mu \mathrm{l}$ of $0.2 \mathrm{M}$ Tris- $\mathrm{HCl}$ buffer $(\mathrm{pH} 7 \cdot 7)$ containing $75 \mathrm{mM} \mathrm{MgCl}_{2}$, and $50 \mu$ of $50 \mathrm{mM}$ UMP-Na (Shigma Chemical Co, Saint Louis, USA). The reaction was started by adding the substrate at $37^{\circ} \mathrm{C}$. After 60 minutes the reaction was terminated by placing the tubes in boiling water for three minutes. Then $2.25 \mathrm{ml}$ of distilled water was added to the mixture and agitated. After centrifugation, the resulting supernatant was used for the HPLC analysis. A Shimadzu liquid chromatograph (Shimadzu, Kyoto, Japan) consisting of a pump (LC-3A), an automatic sample injector (SIL-2A), a column oven (CTO-2A), a variable wavelength spectrophotometer (SPD-1), and an integrator (C-R1A) was used. Flow rate, oven temperature, and detector wavelength were set at $1.0 \mathrm{ml} / \mathrm{min}$, $40^{\circ} \mathrm{C}$, and $254 \mathrm{~nm}$, respectively. The column $(150 \times$ $4 \mathrm{~mm}$ ) used was packed with reversed phase (ODS) silica. The mobile phase was $5 \%$ methanol containing $5 \mathrm{mM} \mathrm{KH}_{2} \mathrm{PO}_{4}$ and $0.2 \mathrm{mM} 1$-decanesulphonic acid. Samples were cooled at $4^{\circ} \mathrm{C}$ during a series of analyses, and $10 \mu \mathrm{l}$ were automatically injected at seven minute intervals. The activity in dialysed erythrocytes was also determined by the original method, ${ }^{10}$ using buffered substrate purified by ion exchanger. The unit of activity was expressed as micromoles of uridine formed per $\mathrm{g} \mathrm{Hb}$ per hour.

Haemoglobin ( $\mathrm{Hb}$ ) concentrations in $\mathrm{RBC} /$ saline were determined using a haemoglobin counter (TOA Medical Electronic Co, Tokyo, Japan), which directly measured $\mathrm{Hb}$ concentrations spectrophotometrically as cyanmethemoglobin. Blood lead concentrations $(\mathrm{Pb}-\mathrm{B})$ were determined by the method previously reported ${ }^{11}$; ALA-D by the standardised European method $^{12}$; zinc protoporphyrin (ZP) by means of a haematofluorometer (Buchler Instruments, Fort Lee, NJ, USA); delta-aminolaevulinic acid in urine (ALA-U) by the method of Tomokuni and Ogata ${ }^{13}$; and coproporphyrin in urine (CP-U) by the method of Soulsby and Smith. ${ }^{14}$

\section{Results}

In our original method commercially available UMP was purified by ion exchange chromatography to provide the low blank values for the assay. UMP (free acid) is a labile compound and spontaneously decomposes into uridine, which is found in small quantities as a contaminant in commercial UMP. UMP-Na is rather more stable than the free acid and in the present study UMP-Na was used as the substrate without any purification. Figure 1 shows the chromatographic separation of the product (uridine) from the substrate

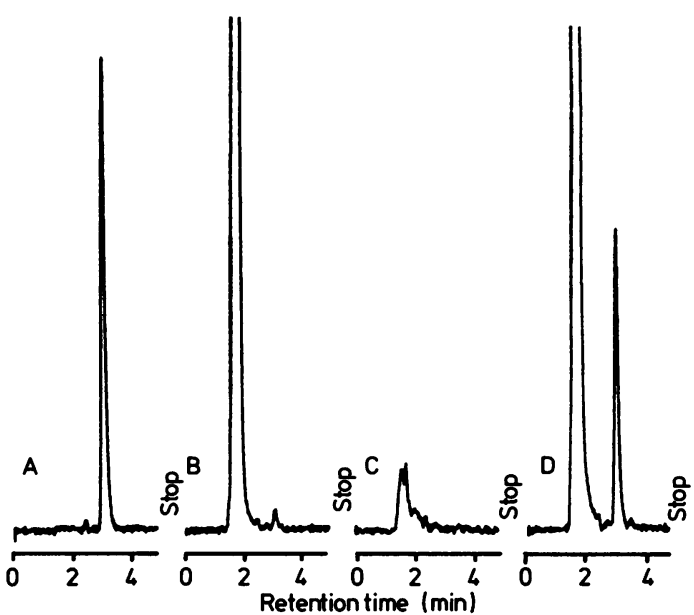

Fig 1 Separations of uridine from UMP and blood components. $A ; 10 \mu M$ uridine, $B$; blank without enzyme solution, $C$; blank without substrate $(U M P)$, and $D ; U M P$ incubated with enzyme solution.

and from erythrocyte constituents. Peak height or area of uridine shows P5N activity. Excellent resolution is achieved in less than four minutes. In the blank without addition of substrate there is no peak corresponding to uridine. Hence the blank for each sample may be omitted in routine analyses. In the blank without addition of enzyme solution a minute peak corres sponding to uridine is detected, indicating that the substrate used contains a small amount of uridine as an impurity or a decomposition product. Thus the blank value must be subtracted from the uridine concentrations obtained. The data obtained by the present method (y) compared well with those using the original method $(x): y=1.003 \times+0.119, n=28$, $\mathrm{r}=0.99$ (data not shown).

In table 1 the data showing the relation between $\mathrm{Pb}-\mathrm{B}$ and P5N activity and other indicators of lead effect are given. A good negative correlation was found between $\mathrm{Pb}-\mathrm{B}$ and $\mathrm{P} 5 \mathrm{~N}$ activity (fig 2) and between $\mathrm{Pb}-\mathrm{B}$ and $\mathrm{ALA}-\mathrm{D}$ activity. The correlation coefficient for $\mathrm{Pb}-\mathrm{B} v \mathrm{P} 5 \mathrm{~N}$ is greater than those for $\mathrm{Pb}-\mathrm{B} \vee \mathrm{ZP}$, ALA-U, or CP-U. The dose-effect relation for the various biological parameters are

Table 1 Correlations between $P b-B$ and its biological effect

\begin{tabular}{ll}
\hline $\begin{array}{l}\text { Regression } \\
\text { equation }\end{array}$ & $\begin{array}{l}\text { Correlation } \\
\text { coefficient }\end{array}$ \\
\hline $\log \mathrm{P} 5 \mathrm{~N}=-0.00793 \mathrm{~Pb}-\mathrm{B}+1.312$ & $\mathrm{r}=-0.80$ \\
$\log \mathrm{ALA}-\mathrm{D}=-0.0128 \mathrm{~Pb}-\mathrm{B}+1.819$ & $\mathrm{r}=-0.87$ \\
$\log \mathrm{ZP}=0.0158 \mathrm{~Pb}-\mathrm{B}+1.622$ & $\mathrm{r}=0.73$ \\
$\log \mathrm{ALA}-\mathrm{U}=0.00876 \mathrm{~Pb}-\mathrm{B}+0.154$ & $\mathrm{r}=0.70$ \\
$\log \mathrm{CP}-\mathrm{U}=0.00677 \mathrm{~Pb}-\mathrm{B}+1.443$ & $\mathrm{r}=0.32$
\end{tabular}


Table 2 Mean values (SDs) of Pb-B ( $\mu \mathrm{g} / 100 \mathrm{~g}), P 5 N(u), A L A-D(u), Z P(\mu g / 100 \mathrm{~g}), A L A-U(\mathrm{mg} / \mathrm{g} \mathrm{Crn})$, and $C P-U(\mu g / g C r n)$ in the different groups; less than 10, 20, 30, 40, 50, and over $50 \mu \mathrm{g} P b-B / 100 \mathrm{~g}$

\begin{tabular}{|c|c|c|c|c|c|c|c|}
\hline Groups & No & $P b-B$ & P5N & $A L A-D$ & $Z P$ & $A L A-U$ & $C P-U$ \\
\hline$<10$ & 35 & $6.6 \quad(1.7)$ & \multirow{6}{*}{$\begin{array}{l}17.7(3.0) \\
17.4(1.2) \\
15.3(2.6) \\
15.1(1.2) \\
13.7(2.7) \\
13.5(1.2) \\
12.1(2.4) \\
12.0(1.2) \\
8.5(2.0) \\
8.2(1.3) \\
5.8(1.9) \\
5.6(1.4)\end{array}$} & \multirow{6}{*}{$\begin{array}{l}62.3(11.3) \\
61.7(1.2) \\
39.9(10.4) \\
38.9(1.3) \\
30.7(7.3) \\
30.2 \quad(1.3) \\
24.0 \quad(5.8) \\
23.4(1.3) \\
18.8(3.4) \\
18.6(1.2) \\
13.1 \quad(3.7) \\
12.6 \quad(1.3)\end{array}$} & \multirow{6}{*}{$\begin{array}{cc}63.7 & (31 \cdot 7) \\
57.5 & (1.5) \\
78.0 & (42.7) \\
69.2 & (1.6) \\
102 & (49.4) \\
93.3 & (1.6) \\
179 & (94.9) \\
158 & (1.6) \\
287 & (139) \\
257 & (1.6) \\
493 & (353) \\
398 & (2.1)\end{array}$} & \multirow{6}{*}{$\begin{array}{l}2.3(0.8) \\
1.5(1.3) \\
2.7(1.0) \\
2.2(1.3) \\
3.0(1.0) \\
2.4(1.3) \\
3.3(1.0) \\
2.6(1.3) \\
5.1(0.9) \\
4.0(1.4) \\
6.4(3.7) \\
5.6(1.8)\end{array}$} & \multirow{6}{*}{$\begin{array}{l}50.9 \\
34.7 \\
49.6 \\
37.2 \\
53.6 \\
38.9 \\
57.0 \\
38.0 \\
90.0 \\
61.7 \\
200 \\
155\end{array}$} \\
\hline$<20$ & 33 & $15 \cdot 7 \quad(3.4)$ & & & & & \\
\hline$<30$ & 44 & $25 \cdot 2 \quad(3 \cdot 3)$ & & & & & \\
\hline$<40$ & 32 & $33.9 \quad(3.0)$ & & & & & \\
\hline$<50$ & 8 & $44 \cdot 1 \quad(2 \cdot 3)$ & & & & & \\
\hline$\geqslant 50$ & 7 & $62 \cdot 8(11 \cdot 7)$ & & & & & \\
\hline
\end{tabular}

1st row: arithmetic mean (arithmetic SD). 2nd row: geometric mean (geometric SD).

shown in fig 3 and table 2 . The group was subdivided into groups with $\mathrm{Pb}-\mathrm{B}$ levels at less than $10,20,30,40$, 50 , and over $50 \mu \mathrm{g} / 100 \mathrm{~g}$, and the geometric means and SD of P5N, ALA-D, ZP, ALA-U, and CP-U were plotted against the $\mathrm{Pb}-\mathrm{B}$ values (fig 3). ALA-D

Table 3 Correlations between P5N and other biological effects of lead

\begin{tabular}{ll}
\hline $\begin{array}{l}\text { Regression } \\
\text { equation }\end{array}$ & $\begin{array}{l}\text { Correlation } \\
\text { coefficient }\end{array}$ \\
\hline $\log$ P5N $=\quad 0.497 \log$ ALA-D +0.371 & $r=0.73$ \\
$\log$ P5N $=-0.316 \log$ ZP +1.756 & $r=-0.68$ \\
$\log$ P5N $=-0.504 \log$ ALA-U + 1.311 & $r=-0.62$ \\
$\log$ P5N $=-0.618 \log$ CP-U +1.397 & $r=-0.34$ \\
\hline
\end{tabular}

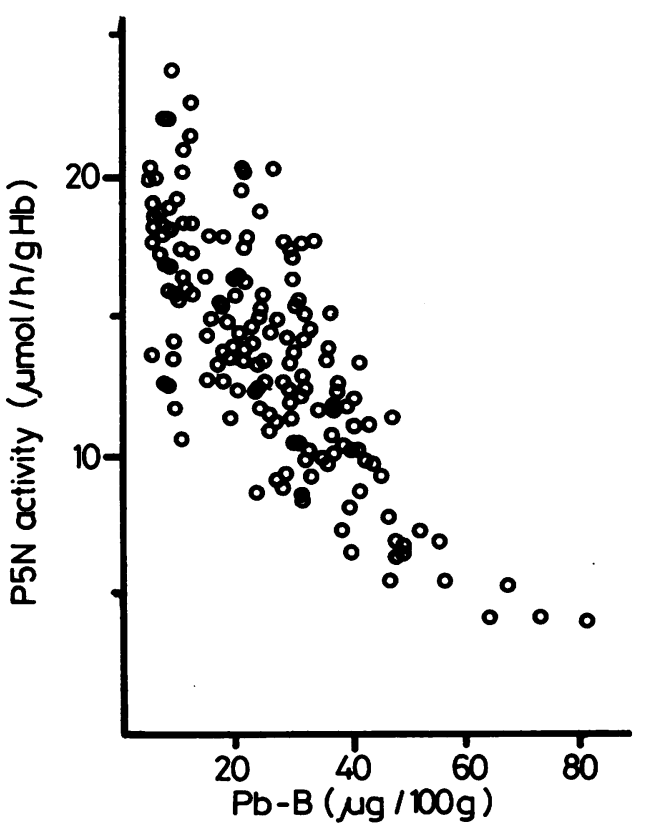

Fig 2 Relation between $\mathrm{Pb}-\mathrm{B}$ and P5N activity. activity shows $37 \%$ and $70 \%$ reductions with $\mathrm{Pb}-\mathrm{B}$ in the range $10-20$ and $40-50 \mu \mathrm{g} / 100 \mathrm{~g}$, respectively, compared with a $\mathrm{Pb}-\mathrm{B}$ of less than $10 \mu \mathrm{g} / 100 \mathrm{~g}$. The rate of inhibition of ALA-D decreased considerably at $\mathrm{Pb}-\mathrm{B}$ values over $40 \mu \mathrm{g} / 100 \mathrm{~g}$, levels that are important for monitoring lead exposure. By contrast, P5N shows a more linear reduction in activity with a

Table 4 Validity of $P 5 N, A L A-D, A L A-U$, and $Z P$ at $P b-B \geqslant 40 \mu g / 100 \mathrm{~g}$

\begin{tabular}{|c|c|c|c|}
\hline & $S E$ & $S P$ & $V D$ \\
\hline \multirow{2}{*}{$\begin{array}{c}\text { P5N (u): } \\
12 \\
10 \\
8 \\
\text { ALA-D (u): } \\
25 \\
23 \\
20 \\
\text { ALA-U (mg }\end{array}$} & $\begin{array}{l}1.00 \\
0.93 \\
0.60\end{array}$ & $\begin{array}{l}0.74 \\
0.93 \\
1.00\end{array}$ & $\begin{array}{l}1.74 \\
1.86 \\
1.60\end{array}$ \\
\hline & $\begin{array}{c}1.00 \\
0.93 \\
0.80 \\
\text { g Crn): }\end{array}$ & $\begin{array}{l}0.74 \\
0.88 \\
0.92\end{array}$ & $\begin{array}{l}1.74 \\
1.81 \\
1.72\end{array}$ \\
\hline $\begin{array}{l}4 \\
4.5 \\
5 \\
Z P(\mu \mathrm{g} / \mathrm{dl} \text { RB }\end{array}$ & $\begin{array}{l}0.67 \\
0.67 \\
0.53 \\
C):\end{array}$ & $\begin{array}{l}0.88 \\
0.97 \\
0.98\end{array}$ & $\begin{array}{l}1.55 \\
1.64 \\
1.51\end{array}$ \\
\hline $\begin{array}{l}100 \\
150 \\
200\end{array}$ & $\begin{array}{l}1.00 \\
0.93 \\
0.73\end{array}$ & $\begin{array}{l}0.64 \\
0.83 \\
0.92\end{array}$ & $\begin{array}{l}1.64 \\
1.76 \\
1.65\end{array}$ \\
\hline
\end{tabular}

SE, sensitivity; SP, specificity; VD, validity.

Table 5 Effect of sample storage on the activity

\begin{tabular}{|c|c|c|c|c|}
\hline \multirow{3}{*}{$\begin{array}{l}\text { Sample } \\
\text { No }\end{array}$} & \multicolumn{4}{|c|}{ P5N activity $(\mu \mathrm{mol} / \mathrm{h} / \mathrm{g} \mathrm{Hb})$} \\
\hline & \multicolumn{4}{|c|}{ Days after sampling } \\
\hline & 0 & 7 & 14 & 28 \\
\hline $\begin{array}{l}1 \\
2 \\
3 \\
4 \\
5 \\
6\end{array}$ & $\begin{array}{l}16.2 \\
18.4 \\
16.4 \\
16.9 \\
14.3 \\
15.3\end{array}$ & $\begin{array}{l}16.8 \\
18.3 \\
16.1 \\
16.9 \\
14.0 \\
15.3\end{array}$ & $\begin{array}{l}15.7 \\
17.8 \\
16.2 \\
16.4 \\
14.0 \\
15.0\end{array}$ & $\begin{array}{l}15.1 \\
14.7 \\
13.8 \\
14.0 \\
13.1 \\
15.1\end{array}$ \\
\hline $\begin{array}{l}\overline{\mathbf{x}} \\
(\%) \\
\text { SD }\end{array}$ & $\begin{array}{c}16-25 \\
(100) \\
1.40\end{array}$ & $\begin{array}{c}16.23 \\
(99.9) \\
1.48\end{array}$ & $\begin{array}{c}15.85 \\
(97.5) \\
1.30\end{array}$ & $\begin{array}{r}14.30 \\
(88.0) \\
0.80\end{array}$ \\
\hline
\end{tabular}



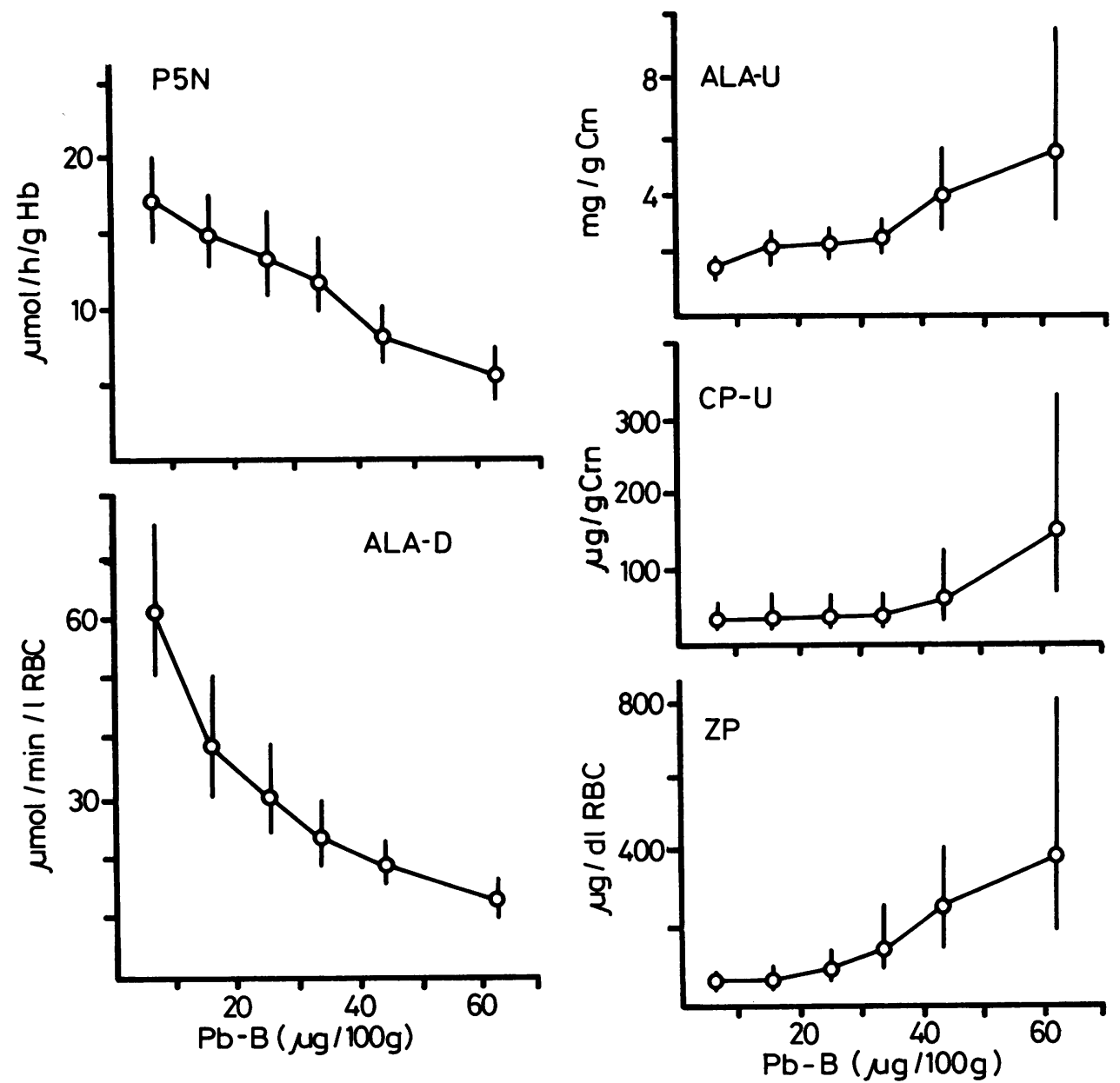

Fig 3 Relation between $\mathrm{Pb}-\mathrm{B}$ and some haematological parameters. Geometrical means (O) and range of $S D$ (vertical line) are shown in different $P b-B$ groups; less than $10,20,30,40,50$, and over $50 \mu \mathrm{g} / 100 \mathrm{~g}$.

rise in $\mathrm{Pb}-\mathrm{B}$ values. $\mathrm{P} 5 \mathrm{~N}$ activity at $\mathrm{Pb}-\mathrm{B}$ of $40-50 \mu \mathrm{g} / 100 \mathrm{~g}$ is only about $50 \%$ of that of levels of less than $10 \mu \mathrm{g} / 100 \mathrm{~g}$. Since a $13 \cdot 2 \%$ inhibition in P5N activity is found even with $\mathrm{Pb}-\mathrm{B}$ segment of $10-20 \mu \mathrm{g} / 100 \mathrm{~g}$, the threshold (no effect) level of $\mathrm{Pb}-\mathrm{B}$ for P5N is less than $10 \mu \mathrm{g} / 100 \mathrm{~g}$. The threshold concentration of $\mathrm{Pb}-\mathrm{B}$ for $\mathrm{ZP}$ is less than $20 \mu \mathrm{g} / 100 \mathrm{~g}$ and $\mathrm{ZP}$ concentrations increase exponentially as $\mathrm{Pb}-\mathrm{B}$ exceeds $30 \mu \mathrm{g} / 100 \mathrm{~g}$. ALA-U and CP-U increase significantly only when $\mathrm{Pb}-\mathrm{B}$ concentrations exceed $40 \mu \mathrm{g} / 100 \mathrm{~g}$.

The data in table 3 shows the relation between P5N and the other biological indicators of effect. Highly significant $(p<0.01)$ correlations were found between all the indicators examined. With respect to P5N the correlations were ALA-D > ZP > ALA-U
$>\mathrm{CP}-\mathrm{U}$. The validity (sensitivity + specificity) of P5N, ALA-D, ZP, and ALA-U was compared for $\mathrm{Pb}-\mathrm{B}$ values over $40 \mu \mathrm{g} / 100 \mathrm{~g}$ (table 4 ). The validity of P5N ( 1.86 at a cut off of $\leqslant 10$ units) is higher than that of all other indicators examined. Table 5 shows the changes in P5N activity during the storage of blood at $4^{\circ} \mathrm{C}$. There is no significant change a week after sampling, whereas at two weeks, the reduction in P5N activity is only $2.5 \%$. Thus P5N activity is fairly stable if the sample is stored at $4^{\circ} \mathrm{C}$.

\section{Discussion}

P5N catalyses the hydrolysis of pyrimidine 5'-monophosphate to yield pyrimidine nucleosides and inor- 
ganic phosphate. Techniques for assay of P5N activity fall into two categories; one based on the determination of inorganic phosphate and the other on the determination of pyrimidine nucleosides. In the conventional method for determining P5N activity the amount of inorganic phosphate released is determined colorimetrically. ${ }^{1}$ Inorganic phosphate (and other sources of inorganic phosphate) are normally present in erythrocytes, so to reduce the blank values the phosphate must be removed by dialysing the lysate before the enzyme assay. It is also necessary to incubate the samples for relatively long periods to release sufficient phosphate. Because of these disadvantages the determination of P5N activity has not been used frequently in the routine monitoring of lead exposure. The other type of assay of P5N activity was reported by Torrance et al..$^{5}$ In this method radioactive CMP $\left({ }^{14} \mathrm{C}\right.$-CMP, cytidine 5 -monophosphate) was used as the substrate, which was adsorbed on to barium sulphate after the reaction had finished and the ${ }^{14} \mathrm{C}$-cytidine formed was counted with a liquid scintilation counter. This method eliminates the need for dialysis of the enzyme solution and is also extremely sensitive. The method cannot easily be carried out in every clinical laboratory, however.

In our assay P5N activity is also determined by measuring liberated pyrimidine nucleosides. The product is separated from the substrate and from red cell constituents by means of HPLC. In this method dialysis of the samples is not necessary and the incubation time is shortened because the amount of endogenous uridine is non-detectable and the intensity of the absorption of uridine at $254 \mathrm{~nm}$ is high. In our original method ${ }^{10}$ commercial UMP was purified by ion exchange chromatography to obtain UMP free from uridine. In the present method we used UMP-Na which is more stable than UMP (free acid) and eliminated the purification step. By these modifications the procedure was further simplified. Both methods gave identical results.

The mean control values ( \pm SDs) for P5N activity have been reported as $7 \cdot 1,{ }^{1} 6 \cdot 6 \pm 2 \cdot 0,{ }^{2} 7 \cdot 38 \pm 2 \cdot 56,{ }^{4}$ $9.9 \pm 2 \cdot 5,{ }^{3} 7 \cdot 51 \pm 0.86,{ }^{5}$ and $12.9 \pm 2 \cdot 9 .^{16}$ These results were determined by the method of Valentine $e t$ $a l,{ }^{1}$ using UMP as the substrate. Mean values obtained with CMP as the substrate are $70 \cdot 5-83 \cdot 3 \%$ of those given above. Sato et al established the normal value for P5N in Japanese subjects $(n=209)^{7}$ by the method of Valentine et al, ${ }^{1}$ using CMP as the substrate. Their mean values \pm SDs for 109 men, 100 women, and all subjects are $13.8 \pm 3.0,14.0 \pm 3 \cdot 4$, and $13.9 \pm 3 \cdot 2$, respectively. These values are almost twice those found in American and European subjects. Sato et al suggested that the higher activity found in Japanese subject is due to lower $\mathrm{Pb}-\mathrm{B}$ values. ${ }^{7}$ They obtained a mean $\mathrm{Pb}-\mathrm{B}$ value $( \pm \mathrm{SD})$ of
$7 \cdot 34( \pm 3 \cdot 7) \mu \mathrm{g} / 100 \mathrm{~g}$ in their subjects. No concurrent $\mathrm{Pb}-\mathrm{B}$ values, however, were reported in the studies of the American or European subjects. In the present study the geometric and arithmetic means ( \pm SD) of P5N activity are 17.4 $( \pm 1.2)$ and $17.7( \pm 2.95)$, respectively, in subjects whose $\mathrm{Pb}-\mathrm{B}$ values are less than $10 \mu \mathrm{g} / 100 \mathrm{~g}$ (mean \pm SD $6.58 \pm 1.6 \mu \mathrm{g} / 100 \mathrm{~g}$, table 2). The mean activity of the group is similar to that reported by Sato et al, ${ }^{7}$ taking into account that the substrate used in our methods is UMP.

In a previous study we found a significant correlation between $\mathrm{P} 5 \mathrm{~N}$ and $\mathrm{Pb}-\mathrm{B}(\log \mathrm{P} 5 \mathrm{~N}=-0.0732$ $\mathrm{Pb}-\mathrm{B}+1 \cdot 27, \mathrm{r}=0.79, \mathrm{n}=68)$ at $\mathrm{Pb}-\mathrm{B}$ values less than $65 \mu \mathrm{g} / 100 \mathrm{~g}{ }^{8}$ In the present investigation we obtained almost the same equation $(\log$ P5N $=$ $-0.00793 \mathrm{~Pb}-\mathrm{B}+1.312, \mathrm{r}=-0.80, \mathrm{n}=161$ ) in lead workers whose $\mathrm{Pb}-\mathrm{B}$ were between 3 and $80 \mu \mathrm{g} / 100 \mathrm{~g}$. These correlation coefficients are compatible with the data of Mohammed-Brahim et $a l^{9}$ who determined P5N activity in a large population that included workers exposed to lead and other heavy metals; they obtained a correlation coefficient of 0.79 between log $\mathrm{P} 5 \mathrm{~N}$ and $\mathrm{Pb}-\mathrm{B}(4.9-73.5 \mu \mathrm{g} / 100 \mathrm{ml})$. According to Paglia et al, correlation coefficients between P5N and erythrocyte lead concentrations are -0.5 and -0.7 (obtained with UMP and CMP as substrate, respectively) in 23 lead intoxicated subjects with $\mathrm{Pb}-\mathrm{B}$ values over $100 \mu \mathrm{g} / \mathrm{dl} \mathrm{RBC}^{3}$ They noted that P5N activity was progressively inhibited until erythrocyte lead concentrations reached $200 \mu \mathrm{g} / \mathrm{dl} \mathrm{RBC}$, at which point the activity was maximally depressed. Our data indicate that P5N activity was sensitive to lead in blood as low as $10-20 \mu \mathrm{g} / 100 \mathrm{~g}$ (fig 3 and table 2). The activity at $\mathrm{Pb}-\mathrm{B}$ of $10-20 \mu \mathrm{g} / 100 \mathrm{~g}$ was reduced by $13 \cdot 2 \%$ compared with that at $\mathrm{Pb}-\mathrm{B}$ levels of less than $10 \mu \mathrm{g} / 100 \mathrm{~g}$. Thus the threshold (no effect) values of $\mathrm{Pb}-\mathrm{B}$ for P5N activity may be less than $10 \mu \mathrm{g} / 100 \mathrm{~g}$. Based on these findings and the description by Paglia et $a l^{3}{ }^{3}$ it appears that P5N activity is progressively inhibited over a wide range of $\mathrm{Pb}-\mathrm{B}$ values between 10 and $100 \mu \mathrm{g} / 100 \mathrm{~g}$, and has a wide field of application in the monitoring of lead effects. By contrast, other parameters seem to have a somewhat restricted application. Although ALA-D is highly sensitive to, and closely correlated with, $\mathrm{Pb}-\mathrm{B}$, the activity is almost completely inhibited with $\mathrm{Pb}-\mathrm{B}$ increases beyond 40 $\mu \mathrm{g} / 100 \mathrm{~g}$ (fig 3), as we have described previously. ${ }^{17} \mathrm{ZP}$ increases exponentially when $\mathrm{Pb}-\mathrm{B}$ exceeds 30 $\mu \mathrm{g} / 100 \mathrm{~g}$ (fig 3) and ALA-U and CP-U also increase exponentially with $\mathrm{Pb}-\mathrm{B}$ over $40 \mu \mathrm{g} / 100 \mathrm{~g}$ (fig 3). These results are comparable with those reported previously. ${ }^{18}$

Strong correlations were found between P5N activity and other biological indicators of lead effect (table 3). Correlation coefficients between $\log \mathrm{P} 5 \mathrm{~N}$ and $\log$ ALA-D, $\log$ ZP, $\log$ ALA-U, and $\log$ CP-U were 
$0.73,-0.68,-0.62$, and -0.36 , respectively. These data compare with the correlations reported by Mohammed-Brahim et al, ${ }^{9}$ whose correlation coefficients of $\log$ P5N $v \log$ ALA-D, $\log$ ZP, and $\log$ ALA-U were $0.76,-0.79$, and -0.60 , respectively. The strong correlations between $\mathrm{P} 5 \mathrm{~N}$ and other biological parameters suggest that the decrease in P5N activity is able to predict the disturbance which lead induces in haem biosynthesis. In male workers exposed to lead and other heavy metals MohammedBrahim et al reported the validity of P5N and ZP as 1.71 and 1.73 , respectively, when $\mathrm{Pb}-\mathrm{B}$ values were greater than $40 \mu \mathrm{g} / 100 \mathrm{ml} .{ }^{9}$ In the present study we obtained a high validity for P5N (1.86 at a cut off of $\leqslant 10$ units) at $\mathrm{Pb}-\mathrm{B} \geqslant 40 \mu \mathrm{g} / 100 \mathrm{~g}$ and this was higher than those of the other indicators examined (table 4). This indicates that P5N is a good discriminator at moderate $\mathrm{Pb}-\mathrm{B}$ values.

Although ALA-D activity is the most sensitive indicator of lead exposure and widely used for this purpose, one disadvantage of the test is that the assay must be carried out immediately after sampling. The enzyme is vulnerable and inactivated during storage. To solve this problem we routinely determine the activity ratio by heat treatment or zinc activation or both, of ALA-D in stored samples. ${ }^{11} 19$ P5N, by contrast, is relatively stable at $4^{\circ} \mathrm{C}$ (table 5). Torrance et al reported that the reduction of P5N activity was only $1.4 \%$ after storage of samples for seven days at $4^{\circ} \mathrm{C} .{ }^{15}$ As the assay of P5N can be carried out with stored samples, it seems to be more suitable than ALA-D for screening lead exposure.

\section{References}

1 Valentine WN, Fink K, Paglia DE, Harris SR, Adams WS. Hereditary hemolytic anemia with human erythrocyte pyrimidine 5'-nucleotidase deficiency. J Clin Invest 1974;54:866-79.

2 Paglia DE, Valentine WN, Dahlgren JG. Effects of low-level lead exposure on pyrimidine 5 -nucleotidase and other erythrocyte enzyme. Possible role of pyrimidine 5 '-nucleotidase in the pathogenesis of lead-induced anemia. $J$ Clin Invest 1975;56:1164-9.

3 Paglia DE, Valentine WN, Fink K. Lead poisoning. Further observations on erythrocyte pyrimidine 5 -nucleotidase deficiency and intracellular accumulation of pyrimidine nucleotide. J Clin Invest 1977;60:1362-6.

4 Ben-Bassat I, Brok-Simoni F, Kende G, Holtzmann F, Ramot B. A family with red cell pyrimidine 5 -nucleotidase deficiency. Blood 1976;47:919-22.

5 Buc H-A, Kaplan J-C. Red-cell pyrimidine 5'-nucleotidase and lead poisoning. Clin Chim Acta 1978;87:49-50.

6 Miwa S, Ishida Y, Takegawa S, Urata G, Toyoda T. A case of lead intoxication: clinical and biochemical studies. Am J Hematol 1981;11:99-105.

7 Sato Y, Sasaki T, Taniguchi N, Saito K. Normal pyrimidine $5^{\prime}$-nucleotidase activity level of Japanese subjects and a significance as a marker for low concentration of lead in blood. Jpn J Hyg 1981;36:518-25.

8 Sakai T, Yanagihara S, Ushio K. A new method for the determination of erythrocyte pyrimidine $5^{\prime}$-nucleotidase $\left(\mathrm{P}^{\prime} \mathrm{N}\right)$ activity in lead workers. Japanese Journal of Traumatology and Occupational Medicine 1985;33:193-200.

9 Mohammed-Brahim B, Buchet JP, Lauwerys R. Erythrocyte pyrimidine $5^{\prime}$-nucleotidase activity in workers exposed to lead, mercury or cadmium. Int Arch Occup Environ Health 1985;55:247-52.

10 Sakai T, Yanagihara S, Ushio K. Determination of 5 -nucleotidase activity in human erythrocytes and plasma using high-performance liquid chromatography. J Chromatogr 1982;239:717-21.

11 Ushio K, Sakai T, Yanagihara S, Watanabe H. Properties of ALA-D ( $\delta$-aminolevulinic acid dehydratase) and the evaluation of lead exposure using heat activation. Jpn $J$ Ind Health 1975;17:475-82.

12 Berlin A, Schaller KH. European standardized method for the determination of delta-aminolevulinic acid dehydratase activity in blood. J Clin Chem Clin Biochem 1974;12:389-90.

13 Tomokuni K, Ogata M. Normal levels of $\delta$-aminolevulinic acid in the spot urines of adult men, as measured by a simplified method. Jpn J Ind Health 1980;22:92-5.

14 Soulsby J, Smith RL. A simplified method for the quantitative determination of urinary coproporphyrin in lead workers. $B r \Phi$ Ind Med 1974;31:72-4.

15 Torrance J, West C, Beutler E. A simple rapid radiometric assay for pyrimidine-5'-nucleotidase. J Lab Clin Med 1977;90:563-8.

16 Paglia DE, Valentine WN, Brockway RA. Identification of thymidine nucleotidase and deoxyribonucleotidase activities among normal isozymes of 5 -nucleotidase in human erythrocytes. Proc Natl Acad Sci USA 1984;81:588-92.

17 Sakai T, Yanagihara S, Kunugi Y, Ushio K. Relationships between distribution of lead in erythrocytes in vivo and in vitro and inhibition of ALA-D. Br J Ind Med 1982;39:382-7.

18 Niinuma Y, Sakai T, Yanagihara S, Ushio K. Relationship between ZP levels by hematofluorometer and the other biological parameters of lead exposure. Japanese Journal of Traumatology and Occupational Medicine 1982;30:816-24.

19 Sakai T, Yanagihara S, Ushio K. Restoration of lead inhibited 5-aminolevulinate dehydratase activity in whole blood by heat, zinc ion, and (or) dithiothreitol. Clin Chem 1980;26:625-8. 